\title{
Mediation Role of Anxiety Sensitivity on the Relationships between Intolerance of Uncertainty and Fear of COVID-19
}

\author{
1 Assoc. Dr. Sakarya University (Turkey) \\ 2 MA. Sakarya University (Turkey) \\ $3 M A$. Dürce University (Turkey) \\ 4 PhD. Düzce University (Turkey)
}

Eyüp Çelik ${ }^{*}$, Eda Biçener ${ }^{2}$, Ümit Bayın ${ }^{3}$ and Erol Uğur ${ }^{4}$

Título: Papel de Mediación de la Sensibilidad a la Ansiedad en las Relaciones Entre Intolerancia a la Incertidumbre y Miedo al COVID-19.

Resumen: El objetivo del presente estudio es explorar el papel mediador de la sensibilidad a la ansiedad en las relaciones entre la intolerancia a la in certidumbre y el miedo al COVID-19. El estudio se realizó con el método de cribado relacional. Los datos de la investigación se recopilaron en línea de 302 personas (hombres $n=76$, mujeres $n=226$ ) con la escala de miedo a COVID-19, índice de sensibilidad a la ansiedad-3, escala de intolerancia la incertidumbre. El resultado tanto del análisis de mediación como del análisis bootstrapping (con un remuestreo de 5000 bootstrap) mostró que la relación entre la intolerancia a la incertidumbre y el miedo al COVID-19 estaba mediada por la sensibilidad a la ansiedad. La sensibilidad a la ansiedad disminuyó el efecto de la intolerancia a la incertidumbre sobre el miedo al COVID-19. Además, al comparar la intolerancia a la incertidumbre y la sensibilidad a la ansiedad en términos de sus niveles predictivos del miedo al COVID-19, se concluyó que la sensibilidad a la ansiedad predijo más el miedo al COVID-19 y que la sensibilidad a la ansiedad incluyó la varianza de la intolerancia a la incertidumbre asociada. con el miedo al COVID-19.

Palabras clave: Ansiedad. Sensibilidad a la ansiedad. Intolerancia a la incertidumbre. Miedo al COVID-19.

\section{Introduction}

Throughout the history of the world, humanity has experienced various pandemics. Studies on previous outbreaks have indicated that people have experienced the fear of the Ebola virus (Blakey et al., 2015) and anxiety about the H1N1 virus (Wheaton et al., 2011). The COVID-19 pandemic is currently being experienced, has brought the concept of fear of COVID-19 to the literature (Schimmenti et al., 2020). Such that suicide cases have been seen in Bangladesh (Mamun \& Griffiths, 2020) and India (Dsouza et al., 2020) because individuals thought they were COVID-19 positive. The fear of COVID-19 has been conceptualized by Schimmenti et al. (2020), and it includes fear of the body/fear for the body, fear of significant others/fear for significant others, fear of not knowing/fear of knowing, and fear of taking action/fear of inaction dimensions. The fear of not knowing/fear of knowing as a cognitive dimension has been explained in terms of having limited information about the virus and excessive information that may be frightening for individuals.

People are faced with different and changing news every day about the new symptoms of the outbreak, its mutation,

* Correspondence address [Dirección para correspondencia]: Eyüp Çelik. Faculty of Education, Sakarya University, 54300 Hendek /Sakarya (Turkey). E-mail: eyupcelik@sakarya.edu.tr

(Article received: 18-2-2021, revised: 2-4-2021, accepted: 1-6-2021)
Abstract: The aim of the present study is to explore the mediation role of anxiety sensitivity on the relationships between intolerance of uncertainty and fear of COVID-19. The study was conducted with the relational method. The research data were collected online from 302 individuals (Male $n=76$, Female $n=226$ ) with Fear of COVID-19 Scale, Anxiety Sensitivity Index-3, and Intolerance of Uncertainty Scale. The result of both mediation analysis and bootstrapping analysis (with 5000 bootstrap resamples) showed that the relationship between intolerance of uncertainty and fear of COVID-19 was mediated by anxiety sensitivity. Anxiety sensitivity decreased the effect of intolerance of uncertainty on fear of COVID19. Moreover, comparing intolerance of uncertainty and anxiety sensitivity in terms of their predictive levels of the fear of COVID-19, it was concluded that anxiety sensitivity predicted the fear of COVID-19 more, and that anxiety sensitivity included the variance of intolerance to the uncertainty associated with the fear of COVID-19.

Keywords: Anxiety. Anxiety sensitivity. Intolerance of uncertainty. Fear of COVID-19.

the vaccine. Recently, it may be said that COVID-19 brings uncertainty in all areas with obscurity about not only its symptoms but also its treatment, when it will end, and the variability of the precautions taken by governments from day to day. In the literature, the tendency to unfavorable reactions emotionally, cognitively, and behaviorally to ambiguous events and situations is defined as an intolerance of uncertainty (Buhr \& Dugas, 2002). In the previous study, it has been found that as the level of intolerance of uncertainty increases, the level of anxiety about the H1N1 virus increases (Taha et al., 2014). Besides, it has been found that individuals with a high level of intolerance of uncertainty want to be tested for the Zika virus more than others (Edwards et al., 2017).

Symptoms of COVID-19 maintain uncertainty, as they generally resemble common flu symptoms and differ between individuals. However, COVID-19 starts with mild symptoms such as sore throat, weakness and shows more severe symptoms such as shortness of breath, high fever in the following days (WHO, 2020). The bodily dimension of the fear of COVID-19 has been explained as being alert to the sensations of the body and protecting the body (Schimmenti et al., 2020). Due to the importance of early diagnosis in the COVID-19, it is possible for people to become more sensitive to their bodily sensations. In the literature fear of physiological symptoms threatening health constitutes the physical dimension of anxiety sensitivity. Anxiety sensitivity also includes cognitive dimension as a fear of losing mental 
control, and social dimension as fear of noticing anxiety symptoms by others (Reiss, 1991). It has been suggested that not only the risk of death but also the social consequences of the disease are effective in the context of suicide cases associated with COVID-19 (Dsouza et al., 2020; Mamun \& Griffiths, 2020). A mediating relationship was found between life satisfaction and subjective vitality fear of COVID 19 and problematic internet use (Peker et al, 2021). Previous research has also indicated that those suffering from SARS (Person et al., 2004) and Ebola (Davtyan et al., 2014) disease faced stigma and social exclusion. Therefore, physical changes and their possible social consequences may increase the fear of COVID-19 in individuals with high anxiety sensitivity. As a matter of fact, in previous studies, it was found that anxiety sensitivity is associated with anxiety about H1N1 (Wheaton et al., 2011) and fear of Ebola (Blakey et al., 2015).

\section{Mediating Role of Anxiety Sensitivity}

Fear is a response to current and identifiable threats, whereas anxiety is a response to potential, unidentified or unrealized threats (Barlow, 2002). However, uncertainty itself can be considered a threat, too (Epstein, 1972). Moreover, people with high intolerance of uncertainty interpret ambiguous information as threatening (Heydayati et al., 2003), and this contributes to increased arousal (e.g., increased heart rate and blood pressure; Greco \& Roger, 2001). Besides, intolerance of uncertainty regarding a specific stimulus, a physical sensation, for example, may result in a variety of interpretations and responses (Greco \& Roger, 2001). When it is considered that anxiety sensitivity is defined as the fear of anxiety-related sensations based on the belief that they may have harmful consequences (Reiss, 1991) and focuses on identifiable stimuli whose results are ambiguous, it can be said that as anxiety sensitivity increases uncertainty may be perceived as a threat and cause fear.

The studies in the literature reveal that intolerance of uncertainty, anxiety sensitivity, and fear of illnesses have significant relationships (Blakey et al., 2015; Taha et al., 2014; Wheaton et al., 2011). In this study, the relationships between intolerance of uncertainty, anxiety sensitivity, and fear of COVID-19 were examined in order to determine whether a similar relationship pattern existed in COVID-19. However, taking these variables together can contribute not only to the structural relationships between variables but also to the functionality of medical and psychological health services. In the study conducted by Horenstein et al. (2019), it was found that the relationship between health anxiety and the possibility of seeking medical help is more robust in individuals with high levels of anxiety sensitivity and intolerance of uncertainty. Also, in another study, it was found that the mediating role of the physical and cognitive dimensions of anxiety sensitivity in the relationship between intolerance of uncertainty and health anxiety (O’Bryan \& McLeish, 2017). In summary, considering that intolerance of uncertainty and fear of COVID-19 may increase the admission to healthcare ser- vices and the intensity of limited healthcare services, examining the mediating role between these variables can provide significant contributions to both the literature and practitioners. It could shed light on whether preventive and remedial interventions for COVID-19 will focus on uncertainty sensitivity in general or uncertainty over anxiety sensitivity in particular. Consequently, it is also important in terms of providing a course of action for the interventions to be carried out against the fear of COVID-19 from the therapeutic perspective. Therefore, in this study, it was examined the mediating role of anxiety sensitivity in the relationship between intolerance of uncertainty and fear of COVID-19.

\section{Hypothesis}

In the current research, there are three hypotheses and hypotheses are presented below.

1) Is there a relationship between anxiety sensitivity, intolerance of uncertainty, and fear of COVID-19?

2) Is there the mediation role of anxiety sensitivity on the relationships between intolerance of uncertainty and fear of COVID-19?

3) Does the effect of intolerance of uncertainty on the fear of COVID-19 differ according to the level of anxiety sensitivity (low, medium, high)?

\section{Method}

\section{Study group}

The data were collected online from 302 individuals (Male $N=76$, Female $N=226$ ). Their age range is 17-57 ( $M$ $=26.47, S D=7.41) .208$ of the individuals participating in the study are single and 94 are married; 92 of them have high school or lower education level, 167 have undergraduate and 43 have graduate degree. Data was collected online during October and November 2020 according to the convenience sampling method.

\section{Measuring Tools}

\section{Fear of COVID-19 Scale}

The data relating to the fear of COVID-19 were collected with The Fear of COVID-19 Scale, developed by Ahorsu et al. (2020) and adapted to Turkish by Satici et al. (2020). The scale is a 5 -point $(1=$ Strongly disagree $-5=$ Strongly agree) Likert-type scale consisting of 7 items and one dimension. There is no reverse-scored item in the scale, and high scores indicate the high fear of COVID-19. As a result of the Confirmatory Factor Analysis performed for the construct validity of the scale, it was seen that the Turkish form of the tool had acceptable fit indexes $\left[\chi^{2}(13, \mathrm{~N}=1304)=\right.$ $299.47, p<.05 ; \mathrm{SRMR}=.061 ; \mathrm{GFI}=.936$; NFI $=.912 ; \mathrm{IFI}$ $=.915 ; \mathrm{CFI}=.915]$. The convergent validity of the scale was determined by examining the correlations between the scores 
obtained from the scale and the scores obtained from the depression $(r=.38)$, anxiety $(r=.55)$, stress $(r=.47)$ scales and the scale was found to have convergent validity. The result of the reliability analysis for the Turkish version showed that the internal consistency coefficient was .847. The internal consistency coefficient of the original form of the Fear of COVID-19 Scale was .82.

$$
\text { Anxiety Sensitivity Index-3 (ASI-3) }
$$

The data on anxiety sensitivity in the study were collected with the Anxiety Sensitivity Index-3 (ASI-3) developed by Taylor et al. (2007) and adapted into Turkish by Mantar et al. (2010). ASI-3 consists of 3 sub-dimensions as physical, social, and cognitive, and each sub-dimension has 6 items. The scale provides a total of 18 items and 5-point Likert type measurement. $(0=$ very little $-4=$ very much). The lowest score that can be obtained from the scale is 18 , while the highest score is 72 . As a result of the reliability analysis of Anxiety Sensitivity Index-3, it was found that it has a high internal consistency coefficient $(a=.93)$, and test-retest reliability is also quite good $(r=.64, p<.001)$.

\section{Intolerance of Uncertainty Scale (IUS-12)}

In the study, the data about the intolerance of uncertainty were collected with the Uncertainty Intolerance Scale, which was developed by Carleton et al. (2007) and adapted to Turkish by Sariçam et al. (2014), and provides a 5-point Likert-type measurement $(1=$ Doesn't suit me at all $-5=$ Completely suits me) with 12 items. The scale has two subdimensions: anticipatory anxiety and debilitating anxiety. Although there are no reverse-scored items in the scale, the scale gives both the relation to sub-dimensions and total score. The overall internal consistency coefficient of IUS-12 is .88. The internal consistency coefficient of the original form of the Intolerance of Uncertainty Scale was .91.

\section{Data Analysis}

This research was carried out using the correlational research design. The simple mediation model was tested with regression-based mediation analysis, which is a statistical method used to help answer the question of how some causal agent $\mathrm{X}$ transmits its effect on Y. PROCESS for SPSS, performs mediation analysis with observed variables and estimates parameters of each equation independently. However, for observed variables, there is no difference generally whether use structural equation modeling or PROCESS (Hayes et al., 2017). Thus, the SPSS version of the PROCESS was used to determine the mediation role of anxiety sensitivity on the relationships between intolerance of uncertainty and fear of COVID-19. Before mediation analysis, data were checked in terms of linearity, normality, and multicollinearity problems. Kurtosis, skewness, and Mahalanobis distance scores were examined for linearity and normality. Variance inflation factors (VIFs) and condition index (CI) methods were used for determining whether there were multicollinearity problems. CI values should be lower than 30 and VIF values lower than 10 to meet the normality assumption. Outliers were checked by using Mahalanobis distances as suggested by Tabachnick and Fidell (2013). The results of these examinations (seen in Table 1) showed that there was no multicollinearity problem among independent variables, and data were normally distributed.

Table 1

Linearity, Normality, and Multicollinearity.

\begin{tabular}{lcccccc}
\hline Variables & $\mathrm{N}$ & Min. & Max. & Skewness & Kurtosis & VIF \\
\hline Fear of COVID-19 & 302 & 7.00 & 33.00 & .380 & -.366 & 1.000 \\
Intolerance of Uncertainty & 302 & 12.00 & 60.00 & -.352 & -.169 & 1.418 \\
Anxiety Sensitivity & 302 & .00 & 68.00 & .405 & 4.655 & -.356 \\
\hline
\end{tabular}

\section{Results}

Table 2 presented the means, the standard deviation of the variables, and their inter-correlations. As shown in Table 2, intolerance of uncertainty and anxiety sensitivity are positively related to fear of COVID-19.

Table 2

Descriptive Statistics and Correlations.

\begin{tabular}{lccc}
\hline & 1 & 2 & 3 \\
\hline Fear of COVID-19 & 1 & & \\
Intolerance of Uncertainty & $.31^{* *}$ & 1 & \\
Anxiety Sensitivity & $.47^{* *}$ & $.54^{* *}$ & 1 \\
\hline$M$ & 18.61 & 39.35 & 25.50 \\
$S D$ & 6.03 & 9.87 & 13.86 \\
\hline$* * 0.01$ & & &
\end{tabular}

\section{Mediating Role of Anxiety Sensitivity}

As shown in Table 3, before mediation analysis, regression analysis showed that intolerance of uncertainty significantly predicted fear of COVID-19 (Coeff. $=.19,95 \% \mathrm{CI}$ : $.12-.25 ; p<.01)$.

Table 3

Regression Coefficients, Standard Errors and Significance Tests for the Regression Model.

\begin{tabular}{lcccccc}
\hline Predictor & Coeff. & $S E$ & $p$ & $F$ & $\mathrm{R}$ & $\mathrm{R}^{2}$ \\
\hline Constant & 11.21 & 1.36 & $<.001$ & \multirow{2}{*}{31.48} & .31 & \multirow{2}{*}{.10} \\
Intolerance of Uncertainty & .19 & .03 & $<.001$ & & & \\
\hline
\end{tabular}

As presented in Figure 1 and Table 4, the result of both mediation analysis and bootstrapping analysis (with 5000 bootstrap resamples) showed that intolerance of uncertainty 
significantly predicts the anxiety sensitivity (Coeff. $=.76$, 95\% CI: .63 - .90; $p<.001$ ), but it doesn't significantly predict the fear of COVID-19 (Coeff. $=.05,95 \%$ CI: $-.03-.12$; $p>.05)$. Anxiety sensitivity significantly predicted fear of COVID-19 (Coeff. $=.19,95 \%$ CI: .14 - .24; $p<.001$ ), and also it decreased the effect of intolerance of uncertainty on fear of COVID-19 (from .19 to .05). Finally, similar results were obtained in both the mediation analysis performed with the sample of the research and the bootstrapping analysis with 5000 resamples. Both analysis results showed that the relationship between intolerance of uncertainty and fear of COVID-19 was fully mediated by anxiety sensitivity. In the present study, it was also examined whether the effect of intolerance of uncertainty on the fear of COVID-19 differs according to the level of anxiety sensitivity (low, medium, high). As seen in Figure 1, when anxiety sensitivity level increased, the prediction level of the intolerance of uncertainty to the fear of COVID-19 increased. In other words, while the relationship between intolerance to uncertainty and fear of COVID-19 is greater in individuals with high anxiety sensitivity, the relationship between intolerance to uncertainty and fear of COVID-19 is lower in individuals with low anxiety sensitivity.

Table 4

Mediational Model Coefficients.

\begin{tabular}{|c|c|c|c|c|c|c|c|c|}
\hline \multirow[b]{3}{*}{ Predictors } & & \multicolumn{7}{|c|}{ Consequent } \\
\hline & & \multicolumn{3}{|c|}{ Anxiety Sensitivity } & & \multicolumn{3}{|c|}{ Fear of COVID-19 } \\
\hline & & Coeff. & $S E$ & $p$ & & Coeff. & SE & $p$ \\
\hline Intolerance of Uncertainty & $a$ & .76 & .07 & .000 & $d$ & .05 & .04 & .221 \\
\hline Anxiety Sensitivity & & ------ & ------ & ------ & $b$ & .19 & .03 & .000 \\
\hline \multirow[t]{3}{*}{ Constant } & $i_{1}$ & -4.50 & 2.76 & .11 & $i_{2}$ & 12.05 & 1.27 & .000 \\
\hline & & \multirow{2}{*}{\multicolumn{3}{|c|}{$\begin{aligned} R=.54, R^{2}=.30 \\
F(1300)=125.29\end{aligned}$}} & & \multicolumn{3}{|c|}{$R=.48 ; R^{2}=.23$} \\
\hline & & & & & & \multicolumn{3}{|c|}{$F(2,299)=43.67, p=.000$} \\
\hline
\end{tabular}

Figure 1

Mediation Effect of Anxiety Sensitivity.

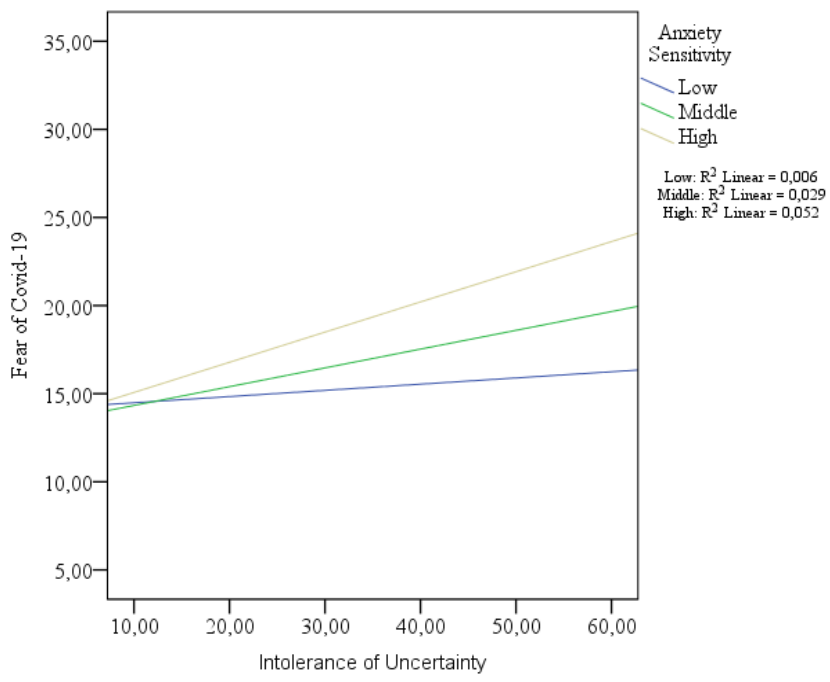

In the mediation analysis, the total, direct and indirect effects of the intolerance of uncertainty on the fear of COVID-19 were examined and presented in Table 5. As seen Table 5, direct effect of the intolerance of uncertainty on the fear of COVID-19 is not significant (Coeff. $=.05$, 95\% CI: $-.027-.118$; $p>.05$ ), but indirect effect of the intolerance of uncertainty on the fear of COVID-19 is significant (Coeff. $=.14,95 \%$ CI: .095 - .194; $p<.001)$. As seen in Table 5 , partially and completely standardized indirect effects of the intolerance of uncertainty on the fear of COVID-19 level are .02 and .23 , respectively.
Table 5

Total, Direct, and Indirect Effects of the Intolerance of Uncertainty on the Fear of COVID-19.

\begin{tabular}{lccc}
\hline \multirow{2}{*}{ Effects } & Estimates of & \multicolumn{2}{c}{$\% 95$ Confidence Interval } \\
\cline { 3 - 4 } & Point $\beta$ & The lowest & The highest \\
\hline Total effect & .19 & .122 & .254 \\
Direct effect & .05 & -.027 & .118 \\
Indirect Effect & .14 & .095 & .194 \\
Partially Standardized & .02 & .015 & .031 \\
Indirect Effect & & & .154 \\
Completely Standardized & .23 & .318 \\
Indirect Effect & & &
\end{tabular}

\section{Discussion}

According to the results of current study, the relationship between intolerance of uncertainty and fear of COVID-19 was mediated by anxiety sensitivity. More specifically, the results showed that the proposed model consisted of the previous studies and explained the role of intolerance of uncertainty by mediating anxiety sensitivity in the fear of COVID19. This may be because anxiety sensitivity reduces the effect of intolerance of uncertainty on fear of COVID-19. Considering the research (McKay et al., 2020; Sat1c1 et al., 2020a) on COVID-19, we can say that our finding is meaningful and consistent. The intolerance of uncertainty and the anxiety sensitivity have a significant relationship with fear of COVID-19 (Hashemi et al., 2020; McKay et al., 2020; Satıc1 et al., 2020b).

Intolerance of uncertainty was found significantly associated with the fear of COVID-19, and this finding was consistent with the results of various studies (Bakioğlu et al., 2020; Elhai et al., 2020; Ercengiz et al., 2020; Hashemi et al., 2020; Jungmann \& Witthöft, 2020; Mertens et al., 2020; 
Satıc1 et al., 2020a; Satıc1 et al., 2020b). The lack of definitive treatment for COVID-19 and an increasing number of deaths due to the disease raised the level of intolerance of uncertainty (Satıc1 et al., 2020b), and when life will return to "normal" is still unclear. Uncertainties about the course of pandemic triggers fear as a defensive emotion. Defensive behaviors are triggered by proximal and distal threats and fear is the conscious emotion of that follows (Coelho et al., 2020). In the COVID-19 pandemic, since the threat is uncertain and continuous, fear can become chronic and harmful. So the COVID-19 pandemic triggered feelings of helplessness and sickness (Bakioğlu et al., 2020). Fear of COVID-19 can worsen the negative effects of the disease, leading people to not think rationally when reacting to COVID-19 (Ahorsu et al., 2020).

The COVID-19 pandemic creates many uncertainties in the lives of individuals and can cause anxiety sensitivity when these uncertain situations are perceived as threatening. Besides threatening people's physical health, COVID-19 also restricts personal freedoms, causes growing financial losses, and negatively affects people's mental health. In this context, the mediational role of anxiety sensitivity in the current study can be explained by the nature of "anxiety". A varying degree of uncertainty is an inseparable part of anxiety (Carleton et al., 2007), and anxiety sensitivity plays an important role in maintaining anxiety (Paulus et al., 2020). Furthermore, in the present study, it was also found that predictive power of intolerance of uncertainty on the fear of COVID-19 differs according to the level of anxiety sensitivity (low, medium, high). This result indicates that the interaction between anxiety sensitivity and intolerance of uncertainty effects the level of intolerance of uncertainty that predicts the fear of COVID-19. In this context, anxiety sensitivity can be instructive in evaluating how intolerance of uncertainty influences fear of COVID-19. Higher levels of anxiety sensitivity may lead individuals to have cognitions that their symptoms are harmful. The consideration in which the virus can be fatal, increases the relevance of anxiety sensitivity (Hashemi et al., 2020; McKay et al., 2020). Beliefs about the uncontrollability of feelings and thoughts related to the pandemic increase individuals' levels of fear (Arslan et al., 2020). Therefore, anxiety sensitivity may be functioned as full mediator for relationship between intolerance of uncertainty and fear of COVID-19, and the interaction be-

\section{References}

Ahorsu, D. K., Lin, C. Y., Imani, V., Saffari, M., Griffiths, M. D., \& Pakpour, A. H. (2020). The Fear of COVID19 Scale: Development and initial validation. International Journal of Mental Health and Addiction.https://doi.org/10.1007/s11469-020-00270-8

Arslan, G., Yıldırım, M., Tanhan, A., Bulus, M., \& Allen, K. A. (2020). Coronavirus stress, optimism-pessimism, psychological inflexibility, and psychological health: Psychometric properties of the Coronavirus Stress Measure. International Journal of Mental Health and Addiction, 1-17. https://doi.org/10.1007/s11469-020-0037-6

Bakioğlu, F., Korkmaz, O., \& Ercan, H. (2020). Fear of COVID-19 and Positivity: Mediating Role of Intolerance of Uncertainty, Depression, Anxiety, and Stress. International Journal of Mental Health and Addiction.https://doi.org/10.1007/s11469-020-00331-y

Barlow, D. H. (2002). Anxiety and its disorders. Guilford Press.

Blakey, S. M., Reuman, L., Jacoby, R. J., \& Abramowitz, J. (2015). Tracing "Fearbola": Psychological predictors of anxious responding to the threat of Ebola. Cognitive Therapy and Research, 39(6), 816-825. https://doi.org/10.1007/s10608-015-9701-9 tween anxiety sensitivity and intolerance of uncertainty is important in the relationship between intolerance of uncertainty and fear of COVID-19.

Research findings on stress, anxiety, and depression associated with the pandemic show that the COVID-19 breakout deeply affects mental health. The relationship between mental health and pandemic is being studied in an increasing number of studies (Bendau et al., 2021; Deniz, 2021). Rehman et al., 2021; Y1ldırm et al., 2021). Therefore, the findings of this study are noteworthy in terms of clarifying the relationship between psychological factors that commonly occur during the pandemic period. That is, the fear of COVID-19, which is positive with intolerance of uncertainty, adversely affects the mental and physical health of individuals. Therefore, specifying the role of anxiety sensitivity may be functional in understanding the psychological contexts that underlie the fear of COVID-19.

\section{Shortcomings and Limitations}

However, the results should be interpreted in terms of shortcomings and limitations of the study. First, the current study was conducted with convenience sample of non-infected individuals. The results of the present research are simply based on the self-reports of the participants. Therefore, the results of this study should be interpreted in the context of its community. Second, the current study is a cross-sectional design. Crosssectional data cannot give evidence for causality between the variables examined. Third, since all data are self-reports, it is inevitable that the research contains methodological biases. Therefore, it is recommended to replicate this study on a sample of individuals with high levels of anxiety sensitivity in order to examine the explanatory power of this model. Therefore, future studies may also collect data that include perspectives of others (e.g., teachers, peers, and family) for a better understanding of the relation between Intolerance of Uncertainty and Fear of COVID-19.

Acknowledgements.- This research did not receive any specific grant from funding agencies in the public, commercial, or not-forprofit sectors.

Bendau, A., Petzold, M. B., Pyrkosch, L., Maricic, L. M., Betzler, F., Rogoll, J., ... \& Plag, J. (2021). Associations between COVID-19 related media consumption and symptoms of anxiety, depression and COVID-19 related fear in the general population in Germany. European Archives of Psychiatry and Clinical Neuroscience, 271(2), 283-291. https://doi.org/10.1007/s00406-020-01171-6

Buhr, K., \& Dugas, M. J. (2002). The Intolerance of Uncertainty Scale: Psychometric properties of the English version. Behaviour Research and Therapy, 40(8), 931-946. https://doi.org/10.1016/S0005-7967(01)00092-4

Carleton, R. N., Norton, M. A. P. J., \& Asmundson, G. J. G. (2007). Fearing the unknown: A short version of the intolerance of uncertainty scale. Journal of Anxiety Disorders, 21(1), 105-117. https://doi.org/10.1016/j.janxdis.2006.03.014

Coelho, C. M., Suttiwan, P., Arato, N., \& Zsido, A. N. (2020). On the Nature of Fear and Anxiety Triggered by COVID-19. Frontiers in Psychology, 11, 3109. https://doi.org/10.3389/fpsyg.2020.581314 
Davtyan, M., Brown, B., \& Folayan, M. O. (2014). Addressing Ebola-related stigma: Lessons learned from HIV/AIDS. Global Health Action, 7(7), 26058. https://doi.org/10.3402/gha.v7.26058. eCollection 2014

Deniz, M. E. (2021). Self-compassion, intolerance of uncertainty, fear of COVID-19, and well-being: A serial mediation investigation. Personality and Individual Differences, 177, 110824. https://doi.org/10.1016/j.paid.2021.110824

Dsouza, D. D., Quadros, S., Hyderabadwala, Z. J., \& Mamun, M. A. (2020). Aggregated COVID-19 suicide incidences in India: Fear of COVID-19 infection is the prominent causative factor. PsyArXiv. https://doi.org/10.31234/osf.io/7xa4b

Edwards, J., Villers, M. S., Heine, R. P., \& Small, M. J. (2017, January). Zika virus screening and testing: Prefences for prenatal diagnosis and tolerance of uncertainty. Society for Maternal-Fetal Medicine 37th Annual Pregnancy Meeting. Las Vegas, Nevada.

Elhai, J. D., Yang, H., McKay, D., \& Asmundson, G. J. (2020). COVID-19 anxiety symptoms associated with problematic smartphone use severity in Chinese adults. Journal of Affective Disorders, 274, 576-582. https://doi.org/10.1016/j.jad.2020.05.080

Epstein, S. (1972). The nature of anxiety with emphasis upon its relationship to expectancy. In C. D. Spielberger (Ed.), Anxiety: Current trends in theory and research, Vol. 2 (pp. 291-337). Academic Press.

Ercengiz, M., Yildiz, B., Savci, M., \& Griffiths, M. D. (2020). Differentiation of self, emotion management skills, and nomophobia among smartphone users: The mediating and moderating roles of intolerance of uncertainty. The Social Science Journal, 1-15. https://doi.org/10.1080/03623319.2020.1833148

Greco, V., \& Roger, D. (2001). Coping with uncertainty: The construction and validation of a new measure. Personality and Individual Differences, 31, 519-534. https://doi.org/10.1016/S0191-8869(00)00156-2

Hayes, A. F., Montoya, A. K., \& Rockwood, N. J. (2017). The analysis of mechanisms and their contingencies: PROCESS versus structural equation modeling. Australasian Marketing Journal (AMJ), 25(1), 76-81. https://doi.org/10.1016/j.ausmj.2017.02.001

Hashemi, S. G. S., Hosseinnezhad, S., Dini, S., Griffiths, M. D., Lin, C. Y., \& Pakpour, A. H. (2020). The mediating effect of the cyberchondria and anxiety sensitivity in the association between problematic internet use, metacognition beliefs, and fear of COVID-19 among Iranian online population. Heliyon, 6(10), Article e05135 https://doi.org/10.1016/j.heliyon.2020.e05135

Heydayati, M., Dugas, M. J., Buhr, K., \& Francis, K. (2003, November). The relationship between intolerance of uncertainty and the interpretation of ambiguous and unambiguous information. [Poster session]. Annual Convention of the Association for Advancement of Behaviour Therapy, Boston, MA, United States.

Horenstein, A., Rogers, A. H., Bakhshaie, J., Zvolensky, M. J., \& Heimberg, R. G. (2019). Examining the role of anxiety sensitivity and intolerance of uncertainty in the relationship between health anxiety and likelihood of medical care utilization. Cognitive Therapy and Research, 43(1), 55-65. https://doi.org/10.1007/s10608-018-9980-z

Jungmann, S. M., \& Witthöft, M. (2020). Health anxiety, cyberchondria, and coping in the current COVID-19 pandemic: Which factors are related to coronavirus anxiety? Journal of Anxiety Disorders, 73, Article 102239 https://doi.org/10.1016/i.janxdis.2020.102239.

Mamun, M. A., \& Griffiths, M. D. (2020). First COVID-19 suicide case in Bangladesh due to fear of COVID-19 and xenophobia: Possible suicide prevention strategies. Asian Journal of Psychiatry, 51, 1-2. https://doi.org/10.1016/j.ajp.2020.102073

Mantar, A., Yemez, B., \& Alkın, T. (2010). Anksiyete duyarlılı̆ı indeksi-3’ün Türkçe formunun geçerlik ve güvenilirlik çalışması, Türk Psikiyatri Dergisi, 21(3), 225- 234. https://toad.halileksi.net/olcek/anksiyeteduyarliligi-indeksi-3

McKay, D., Yang, H., Elhai, J., \& Asmundson, G. (2020). Anxiety regarding contracting COVID-19 related to interoceptive anxiety sensations: The moderating role of disgust propensity and sensitivity. Journal of Anxiety Disorders, $73, \quad$ Article 102233. https://doi.org/10.1016/j.janxdis.2020.102233
Mertens, G., Gerritsen, L., Duijndam, S., Salemink, E., \& Engelhard, I. M. (2020). Fear of the coronavirus (COVID-19): Predictors in an online study conducted in March 2020. Journal of Anxiety Disorders, 74, Article 102258. https://doi.org/10.1016/j.janxdis.2020.102258

O'Bryan, E. \& McLeish, A. (2017). An examination of the indirect effect of intolerance of uncertainty on health anxiety through anxiety sensitivity physical concerns. Journal of Psychopathology and Behavioral Assessment, 39(4). 715-722. https://doi.org/10.1007/s10862-017-9613-y

Paulus, D. J., Brandt, C. P., Lemaire, C., \& Zvolensky, M. J. (2020). Trajectory of change in anxiety sensitivity in relation to anxiety, depression, and quality of life among persons living with HIV/AIDS following transdiagnostic cognitive-behavioral therapy. Cognitive Behaviour Therapy, 49(2), 149-163. https://doi.org/10.1080/16506073.2019.1621929

Peker, A., Cengiz, S., \& Nebioglu-Yıldı, M. (2021). The mediation relationship between life satisfaction and subjective vitality fear of covid-19 and problematic internet use. Journal of Clinical Psychiatry. DOI: https://doi.org/10.5505/kpd.2020.92259

Person, B., Sy, F., Holton, K., Govert, B., Liang, A., Garza, B., ... Zauderer L. (2004). Fear and Stigma: The epidemic within the SARS outbreak. $\begin{array}{llll}\text { Emerging Infectious } & \text { Diseases, } & \text { 10(2), }\end{array}$ 363. https://doi.org/10.3201/eid1002.030750

Rehman, U., Shahnawaz, M. G., Khan, N. H., Kharshiing, K. D., Khursheed, M., Gupta, K., ... \& Uniyal, R. (2021). Depression, anxiety and stress among Indians in times of Covid-19 lockdown. Communit Mental Health Journal, 57(1), 42-48. https://doi.org/10.1007/s10597020-00664-x

Reiss, S. (1991). Expectancy theory of fear, anxiety, and panic. Clinical Psychology Review, 11(2), 141-153. https://doi.org/10.1016/0272 7358(91)90092-9

Satici, B., Gocet-Tekin, E., Deniz, M. E., \& Satici, S. A. (2020a). Adaptation of the fear of COVID-19 scale: Its association with psychological distress and life satisfaction in Turkey. International Journal of Mental Health Addiction. https://doi.org/10.1007/s11469-020-00294-0.

Satici, B., Saricali, M., Satici, S. A., \& Griffiths, M. D. (2020b). Intolerance of uncertainty and mental wellbeing: Serial mediation by rumination and fear of COVID-19. International Journal of Mental Health and Addiction. https://doi.org/10.1007/s11469-020-00305-0

Schimmenti, A., Billieux, J., \& Starcevic, V. (2020). The four horsemen of fear: An integrated model of understanding fear experiences during the COVID-19 pandemic. Clinical Neuropsychiatry, 17(2), 41-45. https://doi.org/10.36131/CN20200202

Sarıçam, H., Erguvan, F. M., Akın, A., \& Akça, M. Ş. (2014). Belirsizliğe tahammülsüzlük ölçeği (BTÖ-12) Türkçe formu: Geçerlik ve güvenirlik çalışmas1. Route Educational and Social Science Journal, 1(3), 148-157. https:// toad.halileksi.net/olcek/belirsizlige-tahammulsuzluk-olcegi bto-12

Tabachnick, B. G., \& Fidell, L. S. (2013). Using multivariate statistics. (Sixth Edition). New Jersey: Pearson Education.

Taha, S., Matheson, K., Cronin, T., \& Anisman, H. (2014). Intolerance of uncertainty, appraisals, coping, and anxiety: The case of the 2009 H1N1 pandemic. British Journal of Health Psychology, 19(3), 592-605. https://doi.org/10.1111/bjhp.12058

Taylor, S., Zvolensky, M. J., Cox, B. J., Deacon, B., Heimberg, R. G., Ledley, D. R., ... Cardenas, S. J. (2007). Robust dimensions of anxiety sensitivity: Development and initial validation of the Anxiety Sensitivity Index-3. Psychological Assessment, 19(2), 176-188. https://doi.org/ 10.1037/1040-3590.19.2.176

Wheaton, M. G., Abramowitz, J., Berman, N. C., Fabricant, L. E., \& Olatunji, B. O. (2011). Psychological predictors of anxiety in response to the H1N1 (swine flu) pandemic. Cognitive Therapy and Research, 36(3), 210-218. https://doi.org/10.1007/s10608-011-9353-3

WHO. (2020). $O$ \& $A$ on coronaviruses (COVTD-19). https://www.who.int/news-room/q-a-detail/q-a-coronaviruses

Yıldırım, M., Geçer, E., \& Akgül, Ö. (2021). The impacts of vulnerability, perceived risk, and fear on preventive behaviours against COVID19. Psychology, Health \& Medicine, 26(1), 35-43. https://doi.org/10.1080/13548506.2020.1776891 